\title{
TUMAČENJE UTISAKA U AMBASADORIMA: STREDEROVA USPAVANA FENOMENOLOGIJA
}

Rad proučava liniju zakašnjelih i pogrešnih tumačenja koja proizvodi glavni lik Džejmsovog romana Ambasadori, Lambert Streder; od samog početka je nesvjestan opalescencije utisaka u slobodoumnoj hedonističkoj sredini pariske više klase, pa ih čita kroz neodgovarajući okvir opterećen uskim moralom malovaroškog Masačusetsa. Nevješt u interpretaciji ambivalentnih pojava i odnosa, pravi jednu grešku za drugom dok smatra da proniče u suštinu stvari - loše procjenjujući karakter Čeda Njusama, kao i odnose sa Marijom i Žanom de Vijone, da bi na kraju u oživljenom sjećanju na jednu pejzažnu sliku doživio umjetničko zadovoljstvo i fenomenološko otrežnjenje.

Ključne riječi: Ambasadori, Henri Džejms,. Streder, svijest, utisci, osjeti, intencije, predmeti.

Tema sazrijevanja je jedna od najčešćih u opusu Henrija Džejmsa (Henry James), i proteže se od prvih romana i pripovijedaka koje je objavio pa do posljednje faze rada; pored druge, „međunarodne” teme, imanentno i kapilarno se nalazi prisutna i u jednom od najuspjelijih romana zrele faze, Ambasadorima (The Ambassadors, 1903). Ovaj rad se bavi analizom i kontekstualizacijom izmjena svijesti kod glavnog junaka, Lamberta Stredera, koji biva poslat u Pariz da iz kandži francuske zavodnice izbavi bogatog i nedužnog mladića Čeda Njusama, a zauzvrat treba da dobije Čedovu majku za ženu, kao i priličan udio u sredstvima firme koju je osnovao Čedov pokojni otac.

Roman je ispripovijedan u takozvanoj figuralnoj narativnoj situaciji, pri čemu se imaginarni svijet, događaji i egzistenti spoznaju i prelamaju kroz svijest (najčešće jednog) stožernog lika, dok deiktičke 
oznake odaju treće lice i vremensku udaljenost neke od formi preterita, što nam Džejms stavlja do znanja već u prvom paragrafu teksta, kada uvodi nove informacije za čitaoca, ali ne i za glavni lik: „Prvo što je Streder učinio kada je stigao u hotel bilo je da upita za svoga prijatelja; ali nije se mnogo razočarao kada je saznao da Vejmarš po svemu sudeći neće stići pre večeri” (DžEJMs 1955: 27). U originalu jasno stoji specifikacija mjesta boravka kao "the hotel”, iako se u tekstu prvi put pominje, a odmah potom čitalac biva uvučen u prisni ton samog Stredera o prijatelju kroz doslovan navod misli: „....neka se ne ljuti dragi dobri Vejmarš." Možda intenzivnije nego ogromna većina romanopisaca, Džejms vidno pokazuje da od prve rečenice gradi izrazito fikcionalan svijet kroz prizmu subjektivnog poimanja vremena, prostora i utisaka o fenomenima međuljudskih odnosa, čime čvrsto pravi protivtežu mogućem faktografskom čitanju, pošto srž romana počiva na istinitom događaju. Džejms je u sveskama 1895. godine zabilježio da su se prethodne godine u Parizu sreli veliki praktičar realizma Vilijam Din Hauels (William Dean Howells) i pisac Džonatan Stardžiz (Jonathan Sturges), oko trideset godina mladi, kome je Hauels dao iskren savjet: „Oh, pa vi ste mladi - neka vam bude drago zbog toga; uživajte u tome i živite. Proživite sve što možete, greška je da ne proživite. Nije toliko važno šta radite, ali živite. Na ovom mjestu sav me život opominje. Sada vidim. Nisam tako učinio - a sada sam star" (nav. prema Jochum 1983: 112). Što se tiče raznih lokacija u francuskoj prestonici, date su sa kartografskom tačnošću: Strederov hotel nalazi se blizu Ulice mira, pošta je kod obale Skribove ulice, iz parka Tiljeri prelazi se Sena, a kroz istoimenu ulicu dolazi se do Luksemburške bašte; Čed Njusam živi na Bulevaru Malezerb, a njegova ljubav, gospođa De Vijone, u Ulici Belšas u predgrađu Sen Žermen. Mnoge druge znamenitosti, kao Bogorodičina crkva i često neimenovani restorani, služe da stvaraju što je moguće realističniju pozadinu kako čitalac ni za tren ne bi posumnjao u autentičnost slike Pariza s kraja XIX vijeka. Ovaj tekst tako pruža primjer slike opipljive stvarnosti kroz prizmu subjektivne svijesti jednog izmaštanog lika, kako je Džejms pisao u ogledu „Umjetnost romana” ("The Art of Fiction”) iz 1884. godine. Navevši da je jedina obaveza romana i prije nego što krenemo da ih 
čitamo to da budu zanimljivi, autor ne ograničava broj načina na koje se ovaj rezultat može postići:

Oni su različiti kao i temperament kod ljudi, a njihov uspeh je srazmeran tome koliko otkrivaju jedan izuzetan um, različit od ostalih. Po svojoj najširoj definiciji, roman je ličan, neposredan utisak o životu. To je prvo što čini njegovu vrednost, a ona je veća ili manja, zavisno od jačine utiska. Ali neće biti nikakve jačine, pa prema tome i nikakve vrednosti, ukoliko ne postoji sloboda osećanja i govora” (DžEJMS 2012: 57).

U ovom romanu se postiže ne samo otkrivanje ljudskog uma kroz utiske i shvatanja Lamberta Stredera, nego se dešava i ispunjava i drugi Džejmsov dezideratum, tj. kompletniji prikaz raznih stanja duha kroz scenski i tečno prikazanu radnju, bez čestih konvencija poput sažimanja narativnog tempa, kojima književnost dotadašnjeg realizma obiluje. Naprotiv, u mnogobrojnim odlomcima koji daju sadržinu Strederove svijesti vrijeme kao hronologija koja odražava fizičke događaje i radnje biva zamijenjeno asocijacijama ideja, koje po svojoj neuhvatljivoj prirodi nadvladavaju linearnost „objektivnog” slijeda očitih uzroka i posljedica iz fizičke stvarnosti. Dajući nam uvid u Strederovu psihu, Džejms otvara ogromno polje za kasnije uvjerljive zaključke o razvrtanju sižea ovog ispisivog teksta (texte scriptible) i u stvari pruža uvid u srž junakovog ponašanja: reflektorsko pripovijedanje odličan je način za osvjetljavanje najdublje uzročnosti Strederove motivacije, kojoj je topos putovanja samo površinska manifestacija. Rad će se mjestimično ispomagati uvidima iz Huserlovih (Edmund Husserl) Logičkih istraživanja da osvijetli neke od pogrešaka u posmatranju fenomenâ koje pravi glavni lik dok ga sustižu utisci u nizu i teško razlučuje umišljanje od suštine stvarî.

Strederovo pomanjkanje vještine u komplikovanim društvenim odnosima pripadnika više klase koji žive u Evropi stavljaće ga kroz cijeli roman u ironičan položaj lika van faze sa samim sobom unutar nove sredine, i pružaće čitaocu katkad daleko više informacija nego što on lično shvata u datom trenutku. Kada upozna gospođicu Mariju Gostri, koju je na prekookeanskom brodu samo vizuelno registrovao, presporo shvata da ona o nekim ličnostima i događajima možda zna i više nego što „ambasador” uopšte i sluti: 
A u onoj meri u kojoj je posumnjao u njenu obdarenost te vrste on joj se, naprotiv, svim srcem predao, mada je prethodno prošao kroz jedan mali otpor svoje svesti. On je odista u neku ruku nagadao šta je ona znala. On je stvarno osećao podsvesno da ona zna stvari koje on ne zna..." (DžEJus 1955: 33)

Kada se sretne sa zemljakom Vejmaršom u Česteru, uviđa da od sveg boravka u Evropi gotovo nikakvu živahnost, veselost ili preporod nije usvojio, nego da ga krasi krutost kao pognutog putnika u vozu, „ugao pod kojim će Vejmarš sedeti sve dok traje ovo mučenje Evrope” (DžEJMS 1955: 44). Streder u toku večernjeg razgovora sa Vejmaršom ne razumije njegove razloge za zatvorenost, pored saznanja o rastavi od žene petnaest godina ranije, pretjeranog rada i neljubavi za Evropu; tek malo kasnije pokušava sebi da predstavi, u donekle plitkoj kolektivističkoj formulaciji, da ideološki položaj koji oličava Vejmarš dolazi iz mentaliteta varošice Milrouz, Konektikat, dok Njusamovi i njihov izaslanik pripadaju drugačijoj matrici, iz Vuleta u Masačusetsu (oba imaginarna, ali uvjerljiva mjesta, sudeći po uskogrudosti moralnih stavova). U samom početku romana i Streder odaje sliku malograđanina, kada priznaje gospođici Gostri da je „slika i prilika potpunog neuspjeha" (DžEJMS 195̌5: 5\%), jer nikad ništa nije stekao, dok mu je još krajnji cilj da zaradi novac obećan za ispunjenu misiju.

U tako sumornom raspoloženju i pojačanoj pasivnosti duha čitaocu se otkrivaju tužni podaci iz Strederovog života, pa se lakše poima njegova malodušnost: oženio se vrlo mlad i propustio dosta zabave koju taj period donosi, a usamljivanje mu je zauzelo sredinu života, pošto mu je umrla žena a kasnije i sin, zbog čega je, paradoksalno, za građansko društvo postao upadljiv stranac. On ne zapaža da bi moglo postojati nešto čudno i unaprijed pripremljeno u „čitanju” njegove misije koje obavlja Marija Gostri bez ijedne greške: „Izgleda, vidite, uz tu ogradu, da sam naslutila i o g. Čedu. To je mladić u koga u Vuletu polažu velike nade, koga je neka rđava žena zgrabila, a njegova porodica odande poslala vas da ga izbavite. Vi ste prihvatili misiju da ga odvojite od te rđave žene. Jeste li sasvim sigurni da je ona za njega vrlo rđava?" (DžEJMs 1955: 63) Da je znao da su Gostrijeva i gospođa De Vijone išle zajedno u školu, Streder sigurno ne bi tako detaljno i otvoreno izložio plan o „spasavanju” Čeda Njusama, a njegova sa- 
govornica je dokazala iskustvo u poznavanju društvenih spletki tako što je vrlo precizno naslutila koliko je gospođa Njusam autoritarna dama iz Vuleta, koja mogućnost kontrole drugih izjednačuje sa dubinom sopstvenog džepa; lukava Marija baca novu udicu Strederu kada poslije svih izvučenih informacija sagovorniku kaže: „Znala sam da još nešto krijete!" (DžEJMS 1955: 73)

Po dolasku u Pariz, Streder još neko vrijeme slijedi uputstva koja stižu preko okeana, ali počinje da upija i utiske sredine u koju je pristigao - susrevši se sa prizorima, zvucima, mirisima i harmonijom svakodnevnog i estetskog u Gradu svjetlosti, učestalo se povodi za asocijacijama koje mu ta sveopšta umjetnost nudi, ispunjava prostore „maglovitim simbolima prizora” i godinama prije kodifikovanja književne fenomenologije kao metoda, ponaša se kao tumač donekle ponesen veličanstvenim umjetničkim djelom. Huserl bi rekao da sama njegova svijest postaje kompleks doživljaja, ali svijet nije nikada doživljaj onoga koji ga misli. Doživljaj je mnijenje-svijeta, sam svijet je intendirani predmet (HusserL 2005: 388). Prolazeći kroz park Tiljeri, u dužim intervalima zastaje i mimo svog zadatka (unosnog ako ga obavi) oličava moć Kantove formule da je lijepo „ono što se bez pojma saznaje kao predmet nužnog dopadanja” (KANT 1991: 131), dok nesvjestan uzroka svog zastajkivanja pomno motri panoramu grada od najsitnijih radnji običnog svijeta - gologlavih djevojaka, staraca i starica pod proljetnim suncem, grabuljara, skupljača hartije, sveštenika i vojnika - koje se sve u perspektivi stapaju u podlogu za dalje zamišljanje srušenog dvorca koji je tu nekada stajao, i Strederova svijest na ovaj način najavljuje stvaranje sloja shematizovanih aspekata, onih koje nam djelo ne prikazuje, ali ih svojom koherencijom omogućava kao prihvatljive produžetke vidljivog vrha „ledenog brijega”. Kada se odupre tim čulnim užicima i vrati pod moralnu upravu gospođe Njusam (široko shvaćeno, pod upravu diskurzivne tvorevine Vuleta, kojoj su i obećana nevjesta i on samo eksponenti), u Strederov duh se uvlači bojazan da bi „skoro svako odavanje priznanja Parizu značilo rušenje sopstvenog autoriteta" dok mu istovremeno naporedo na pragu svijesti taj grad poprima obrise još dubljih temelja civilizacije, ali temelja koje je utilitarna vuletska malograđanština prognala u zabranjenu zonu: „Lebdeo 
je pred njim, toga jutra, taj svetli, prostrani Vavilon, kako kakav ogromni objekat koji se prelivao u duginim bojama, kao kakav blistavi i tvrdi dragulj, na kome nije trebalo ni pokušavati da se razaznaju delovi ili da se označe one razlike koje gode oku” (DžEJMs 1955: 89). Što su protagonisti Ambasadora bliža gravitacija, istorija i silina pariskog hedonizma, to brže i osjetljivije reaguje moralna svijest koju je donio iz masačusetske provincije, i sa binarnom racionalističkom isključivošću ne želi da mu Pariz priraste za srce, kako ne bi stvorio zajedničku vezu sa Čedom. Isprva u francuskoj prestonici Streder i uspijeva da slijedi moralni kodeks odlučnog šampiona izaslanstva gospođe Njusam, ali u otvorenom reflektorskom modusu njegov um se otkriva kao poprište sukobljenih uticaja, čije pojedine stare naslage dopiru iz polusvjesne, svakako refraktovane, lične prošlosti dok je život imao toliko ugođaja da ponudi, a sada se nada „neće li ga se slučajno dotaći krilo zalutalog duha mladosti." Mašta u Parizu zaista reaguje prije nego što je čovjek može zadržati, i ovakvih nagovještaja kašnjenja reflektora ne samo da ima kroz čitav roman, nego oni izomorfno oličavaju Strederovo nesnalaženje sa misijom, sa ličnostima koje će imati da sretne, i sa samom ulogom koju je nesvjestan da igra već decenijama - ironične šeprtlje koja unaprijed pripremljene mreže odnosa i zavjera naprosto ne prepoznaje jer se nalazi van takvog „otmjenog” društva.

Prvi pogled na Čedov stan u Bulevaru Malezerb paradigmatičan je primjer Strederove subjektivne logike: usporen mnoštvom estetskih detalja na fasadi i proporcijama zgrade, sporije se privikava na obavezu lociranja „mete”, koja slučajno ili ne izlazi na balkon - ambivalentnost u ambasadorovom razmišljanju očituje se po kolebanju u odluci je li to uopšte Čed (ispostavlja se da su dug pogled upoznavanja, ako već ne prepoznavanja, razmijenili Streder i mladi Bilhem, Čedov drug). Postaje ubrzo oduševljen Bilhemom, likovnim umjetnikom sa nekim očekivanjima u profesiji, za koga misli da je stopostotni Amerikanac, iako smatra da se i u njemu krije trag zmije, tj. evropske pokvarenosti, što je kod sazrijevajućih Džejmsovih likova jedna od osnovnih osobina u procesu upoznavanja sa autentičnom Evropom. Ponovo se javlja dramska ironija u izaslanikovom zapažanju: „Znači da je ovaj prijatni mladić, kao što je Streder još u početku uočio, posmatrao svet bez ika- 
kve predrasude" (DžEJMs 1955: 114). Bilo bi vrlo povoljno po Strederovu sreću da je i on lično nastupao onako kako odmah vidi da čini Bilhem, za koga uviđa da se okružio isto tako srdačnim i iskrenim drugovima iz Amerike u atmosferi siromaštva punog dobrog raspoloženja, nešto nalik na potonju boemiju u istom gradu između svjetskih ratova. Za izaslanika gospođe Njusam, izgled ove estetski nastrojene grupe dostizao je nivo divne čednosti, što ga je samo moglo utvrditi u pogrešnom uvjerenju da je i Čed isto takav proizvod Vuleta. Prvi put sreće Čeda u pozorišnoj loži, mjestu vrhunske spektakličnosti, na kome se i glumci i publika uzajamno posmatraju (ELLMANN 2010: 52), i sve pretpostavke o mladićevoj suštini koje je gajio padaju u vodu: „Fenomen koji se tako iznenadno pojavio pred njim bio je fenomen tako temeljne promene da je njegova mašta, koja je dotad bila aktivna, sada podstaknuta ovom pojavom, proradila bez mere i granice" (DžEJMS 19555: 122). Jedva dočekavši da se predstava završi, Streder sa Čedom odlazi u restoran da što brže izloži plan za koji unaprijed smatra da će biti prihvaćen; međutim, od uzbuđenja je izgovorio sasvim drukčiji tekst, koji nikad nećemo saznati, a takva radnja je najvjerovatnije bila motivisana time što je pred sobom vidio dovršenu pojavu Čeda, a ne proces kojim je oblikovan njemu trenutno nepoznat mladić. Ni sveznajući pripovjedač ni reflektor ne nagovještavaju poimanje ironije koju sadrži Čedovo pitanje Strederu na izdeklamovani govor: ,Zar vam se ne čini [...] da ima izvesnih pitanja koja bi čovek voleo da prethodno postavi - ma koliko inače bio pod utiskom divnog načina na koji izlažete stvari?" (DžEJMS 1955: 133, kurziv S.M.) U tom razgovoru pod svjetlošću lampe Čed na trenutak zaćuti dok ga Streder posmatra kao izvajanu bistu mladog ljepotana, te pomisli da ima posla sa jednim neukrotivim mladim paganinom; nepun minut kasnije, na demonstraciju palanačkog duha da se u Parizu zadržao samo zbog neke žene, Čed odgovara da je takvo mišljenje nisko i time u sagovorniku budi osjećaj da možda ima posla sa džentlmenom. Nažalost, Streder nije sebi postavio temeljno pitanje koje pobuđuje svako fenomenološko posmatranje stvari, makar i amatersko: da li u opalescenciji različitih karakteristika osoba može biti istovremeno i jedno i drugo? Na nesreću po svoju oštroumnost, Streder nije dopustio mogućnost da fenomen Čeda Njusama osmotri i 
kroz različite nivoe na kojima složena ličnost postoji u mnogim razradama simboličkog poretka a opet zadržava suštinu bez rasapa u ontološki pluralizam. Pred kraj prve trećine romana sažeto se daje vrlo bitna podloga za izmjenu Strederovog mišljenja - lutanja Parizom i upijanja bezbrojnih osjeta došla su kao nužnost, a sa njima i razgovori u Cedovom stanu sa prefinjenim poznavaocima kulture i umjetnosti, gdje je vremešni Amerikanac uvidio ogromnu razliku između shvatanja Vuleta o Francuskoj i samog stanja stvari, i u tako prijatnoj atmosferi prepustio se laganoj izmjeni mišljenja.

Jedan od prekretnih događaja odvija se na prijemu kod vajara Glorijanija, koji je Džejms transponovao iz originalnog dešavanja u kući slikara Džejmsa Vislera (James Whistler), ali je okvir blagotvorne umjetničke atmosfere ipak zadržao kao lokus velikog simboličkog potencijala pogodnog za razvoj maštovitog uvida kod Stredera. Tada se izaslanik mora uvjeriti u tačnost Bilhemove tvrdnje da se Čed nalazi u nevinoj vezi, što se dešava kroz niz utisaka, a jako malo izgovorenih replika sa gospođom De Vijone - kada prisustvuje njenoj neusiljenoj besprekornosti u ophođenju i govoru i uvidi koliko jaku auru dostojanstva isijava, u jednoj rečenici poništava sve predrasude kojima je kljukan u Vuletu i kroz pisma: „Sto se vas tiče, gospođo De Vijone, moram reći da skoro ništa nisam o vama čuo" (DžEJMs 1955: 173, kurziv u originalu). Džejmsu je trebalo više od deset poglavlja knjige da bi izgradio uvjerljivu konstrukciju predrasudama opterećene svijesti, u čije rezonovanje i čitalac lako može povjerovati ukoliko ne da riječ i drugoj strani. U ovoj veličanstvenoj sceni Streder se konačno suočava sa pojavnom istinom u autentičnom kontekstu, i shvata da je gospođa De Vijone prekrasna žena, daleko uzvišenija od iskrivljene slike stvorene kod gospođe Njusam, pa kada Francuskinja krene sa jednim od gospode, Amerikanac osjeti najmirnije odricanje u životu, budući da je prisustvovao emanaciji njene elegancije uživo, kao da se radi o čistom estetskom, a ne i etičkom iskustvu. Tek tada uzvišeni i poneseni govor koji drži Bilhemu o što ugodnijem iskorišćavanju vremena mladosti može stajati na odgovarajućem temelju razvoja Strederovog karaktera i značaju promjene koja se u njemu odigrala, tek tada se Strederovo promašeno životno trajanje može protivstaviti gotovo epifanijskom 
otkriću: iako je život u najboljem slučaju kao limena modla u koju se presipa svijest, nužno je da čovjek stekne iluziju slobode i forme koju zauzima, a bez sjećanja na tu iluziju pojedinac ne vrijedi. Teško je naći u Džejmsovom impresivnom opusu ovako dobro konstruisan metaforički izraz fenomenološkog procesa, kojim dominira intendiranost svijesti na predmete (svih vrsta) u vremenu, a ni aksiološka os se ne gubi iz vida dok saznajući subjekt odabire pojave koje imaju estetsku vrijednost, prevladavajući pasivnost prema svijetu u koji je svijest neraskidivo uronjena, štaviše, konstituisanje realnih predmeta kroz svijest nalazi se na osnovnom stepenu mogućeg sagledavanja koje na raspolaganju ima posmatrač (Husserl 2005: 650-651). Ovo djelovanje čula na Strederovu svijest još se pojačava kada spazi Žanu de Vijone, gospođinu kćerku, koju joj Čed elegantno predstavlja dok stoji pored nje, „vedre, ljupke, stidljive, srećne, divne”: kroz prizor koji sadrži toliku konsumaciju prethodne istorije u trenutku se projavljuje posmatračevo prosvjetljenje, kako kaže pripovjedač, „video je istinu” (DžEJMS 1955: 180). Poslije ovakvog gromovitog utiska kome je kompaktnost prostora i vremena radnje samo dodatno doprinijela, Streder prihvata zdravo za gotovo riječi Marije Gostri da je gospođa De Vijone obrazovala Čeda za svoju Žanu, koju od tada gleda kao utjelovljenje eterične slobode („bila je slobodna onako kako je ona sama shvatala slobodu”), i savršenog vaspitanja, što predmet njegovog posmatranja izdiže na nivo apsoluta bez ijednog drugog sličnog člana u istoj kategoriji - tada možemo postaviti pitanje koliko je izaslanikova percepcija racionalna, ali preimućstvo reflektorske naracije upravo leži u tome što stvara odstojanje između zanesenog lika i obavještenijeg čitaoca, svjesnog odstojanja između pripovjedačke instance i neznanja lika. Tako se Streder nalazi u sve većoj nemogućnosti da gospođi Njusam saopšti suštu istinu, jer je rastrzan tolikom opalescencijom suštine posmatranih fenomena, pri čemu oni sami u svakoj novoj iteraciji pozicioniraju sebe u drukčiju saznajnu ravan i vječito mijenjaju koordinate. U svakom aktu primjećivanja jednog predmeta javljaju se nove karakteristike, takozvana paralelna imaginativna osjenčenja, pa bi se u idealu savršenog odslikavanja osjenčenje podudaralo sa potpunom slikom (HusserL 2005: 569), što našem junaku neprekidno izmiče u 
aktualizaciji. Kada dobije protivrječne naznake da će se Čed možda vezati za gospođu De Vijone, a možda i neće, pokušava da pobjegne od odgovornosti koju sobom nose dvosmislenost njegove misije i moguće upropaštavanje mladićeve budućnosti, pa se simbolično okrepljuje u sakralnoj atmosferi Bogorodičine crkve - tu sreće narečenu gospođu, i u zdanju blagorodne žrtve dolazi do analognog zaključka:

Da nije nevina [veza], zar bi ona obilazila crkve? A u crkve žena takve vrste kakvom ju je on smatrao ne bi nikad ušla radi bestidnog izlaganja svog greha. Ona ih je obilazila radi stalne pomoći, radi snage, radi spokojstva - i ona je tu uzvišenu podršku [...] nalazila tu iz dana u dan. (DžEJMs 1955: 234)

Ne znajući koje od desetina naslaganih objašnjenja da prihvati, Streder osjeća da se ili izdigao ili potonuo ispod njih, te da mu je bolje da prihvati slom i cinizam nego lucidnost, koje mu sve vrijeme - a da on to uporno ne shvata - taktički nedostaje. Na ručku sa gospođom De Vijone zakašnjelo razumijevanje društvenih odnosa na njega ostavlja vrlo jak utisak i nemoćno biva sve svjesniji da mu situacija izmiče iz ruku, zbog čega je i predložio da ručaju, pa dobio nekakvu naknadu za predaju poslije neuspjelog učešća u misiji čiji tok nije bio sposoban da nasluti. Zeleći Čedu dobro, gospođa De Vijone predlaže Strederu da mladić provede neko vrijeme u domovini, pa da dokaže čvrstinu tako što neće sklopiti brak koji majka sprema da nametne: Streder to prihvata jer je obavezan čašću prema Čedu, a samim tim i prema Mariji de Vijone. Tri dana kasnije dramska dinamika se pojačava, jer Strederu stiže negativno intoniran telegram od gospođe Njusam, poslije čega nastaje ozbiljno moralno kolebanje - da li da prihvati Čedov ostanak ili polazak s njim u Ameriku, ili da još dobije u vremenu, što i sam emfatično potvrđuje na mladićevo pitanje: „Osećate draž ovdašnjeg življenja?" (DžEJus 1955: 251) Sav tok događaja koje je Streder djelimično uzrokovao ili im prisustvovao, uz opširne refleksije i (re)konstrukcije mogućih uzroka i posljedica, stavljen je ad acta paktom koji sada inicira stariji muškarac:

„Vi dakle, utoliko više, uvidate šta mi dugujete.”

„Dobro, ako zaista uviđam, kako mogu da platim?”

„Time što me nećete napustiti. Što ćete ostati uz mene.” 
„O, slušajte...!"

Silazeći niz stepenice, Čed ga čvrsto udari rukom po ramenu, što je bilo kao neko obećanje. (DžEJMS 1955: 253)

U ovaj gest je stala potpunija istina o pravom Čedu nego što je to nevješti Streder mjesecima pokušavao da satka od razgovora ispunjenih nagovještajima, u kojima je mladi Amerikanac sazdao nekoliko velova oko sebe i stvarnih namjera u vezi sa gospođom i gospođicom Vijone, a starijem su najviše odmogle upravo one džejmsovske situacione nedorečenosti kada migovi, pokreti, intonacija, a posebno razne sjenke preko lica i sjaj u očima, otvaraju široko polje za odabir jedne ili druge strane imanentne ambivalencije. Kako shvata da neminovno stiže „ambasadorska” delegacija iz Amerike da ga zamijeni, tako se odlučnije drži nove preobražene uloge, sa izrazito fenomenološkim vokabularom iskustva, doživljaja i vremena: „Zar nije još koliko juče sedeo kraj njenih nogu, držao se za njene skute i jeo iz njene ruke? Srazmere su se izmenile, a uvek su srazmere, filozofirao je on, bile bitni uslovi opažanja i osnovi mišljenja” (DžEJMS 1955: 262). U istom razgovoru sa Marijom Gostri, razriješeni „ambasador” dramatično okreće tačku gledišta u neproživljenu potencijalnost, koju sada na posredniji način poima, ako je već ne može iskusiti u vremenskom odsječku kome je pripadala:

Ali nikada tu blagodet [mladost] nisam imao u pravo vreme - što u stvari znači da samu stvar nikad nisam imao. [...] Iako su njih dvoje dovoljno mladi, neću reći da su baš u najsvežijoj, u svojoj apsolutno prvoj mladosti; jer to nema nikakve veze sa ovim. Stvar je u tome što oni predstavljaju prvu moju mladost. Da, oni su moja mladost... (DžEJMs 1955: 263, kurziv u originalu)

Kada pristignu Sara Pokok (Čedova sestra), njen muž Džim i njegova sestra Mejmi, brzo uviđaju - od Džimovog priprostog komentara da ni on ne bi išao iz Pariza do Sarinog sjajnog pogleda ka Strederu i malo piskave intonacije u razgovoru sa gospođom De Vijone - da je Streder sasvim prešao na stranu francuske sredine i njenih žitelja, a obje strane znaju da ona druga o tom ishodu ima svijest, čime se prećutno potvrđuju i pretpostavke i sigurnost u pretpostavke, budući da utisci nastanjuju nesigurno polje na granici mašte sve dok se 
intersubjektivno ne potvrde u empiriji. Sa tačke gledišta prvog lica, intersubjektivnost nastupa kada se podvrgnemo činovima empatije. Intersubjektivno iskustvo je empatijsko iskustvo; dešava se tokom naše svjesne atribucije intencionalnih činova drugim subjektima, kada se stavljamo u položaj drugoga. Ovo iskustvo se ostvaruje kada zamislimo da postoji cilj naše askripcije činova kao iskustveni subjekt i zapitamo se koja naša vjerovanja su opravdana u toj poziciji (BEYER 2003: par. 7.3). Stariji Amerikanac neko vrijeme provodi u neizvjesnosti metapercepcije u koju se upušta kada nije siguran u koji krak račvaste staze treba da zagazi, pa ga živo zanima da se uvjeri kako su i mladi Amerikanci zapazili da je Čed drugačiji, ali to svjedočanstvo mu nije stiglo. To da je Streder nesposoban da donosi racionalne odluke i pravi manipulativne planove potvrđuje se novim uvidom u njegovu podložnost utiscima, pred izlazak iz stana gospođe De Vijone, čija ukupna elegancija mu ostavlja gord, sjetan i umilan prizor:

Nesumnjivo, od toga je pola bilo tvorevina njegove uobrazilje, ali njegova uobrazilja bila je nešto sa čim je on, usred starih navoštanjenih parketa, bledih, crvenih i zelenih abažura, pseudoklasičnih svećnjaka, uvek, neminovno morao da računa. (DžEJMs 1955: 314)

Ovim nam se pruža još jasniji uvid u povodljivost Lamberta Stredera za aurom čulnosti kojom isijava „stara” Evropa, i možemo zaključiti da je uz ovako snažne stimuluse sve vrijeme bio smanjeno uračunljiv i sposoban za povjereni mu zadatak - nažalost, nije intendirao svijest ka pronicanju u dublje slojeve pojava koje su ga tako intenzivno opčinjavale. U istom razgovoru puca i koprena lažnog znanja koje je gajio o Žani de Vijone: vođen (još uvijek) vuletskom logikom da u vezu stupaju mladi muškarac i mlada žena, za vrhunsko otkrovenje smatrao je hipotezu da je ljubav između Čeda i Žane najdublji skriveni sloj, i primjetno se zbunjuje kada od njene majke sazna da se udaje za njemu nepoznatog gospodina De Monbrona, takođe mlađe dobi. Ovim se pokazuje da je Strederova svijest bila isuviše kruta i jednoobrazna da bi razumjela svu fluidnost opalescencije ljudskih subjekata u beskrajno izmjenjivoj mreži društvenih odnosa, da nije ni uračunao zamršenost kodova po kojima tadašnja prestonica Evrope funkcioni- 
še: obična sjedeljka za tili čas se pretvori u višesatnu verbalnu gozbu na brojne teme, a utisci sa gozbe u žive slike inicijacije u hedonistički elizijum, no ta složenost (sasvim suprotno vuletskoj provinciji) ne ukida se povratkom redovnim dužnostima u domaćinstvu. Strederu je nekoliko puta promakla potpuno očita osobina francuske porodice iz višeg sloja da za brak ne mora postojati zaljubljenost kao preduslov, i da se platonske ljubavničke veze kod supružnika ne sankcionišu ni približno oštro kao u Masačusetsu.

U hotelu u kojem je odsjela gospođa Pokok ponovo ga vara percepcija, kada se predaje energiji prazne sobe u kojoj stoje pisma gospođe Njusam, na šta malo ustukne i nastavi sa čekanjem Sare; tada zapaža odsjaj ženske haljine na balkonu, očekujući da se ukaže Sara - na njegovo iznenađenje, sreće mladu bezazlenu Mejmi, koja je ostala da provodi vrijeme po svom nahođenju. Koliko je njegovo opažanje opterećeno uskogrudim obrascima dobro se vidi po tome što Mejmi izgleda kao „protivrječnost Sari”, dok Streder prekasno uviđa detalje, kako se napominje: „Kada se bolje pogledalo...” (DžEJMs 1955: 329) Nesvjesni pritisak od dejstva i „prisustva” gospođe Njusam koja su se osjećala na ulasku u sobu (zbog označitelja u obliku pisama sa poznatim rukopisom, koja su pokolebala izaslanika) tada je nestao, pa je junak uronio u prisjećanje na susrete sa Mejmi u Vuletu, od kolijevke do čajanki. Tako djeluje na dva fenomenološka polja: konstituiše predmet kao opažen, za šta je potreban čin opažanja, a i predstavlja ga svijesti kao zapamćeni predmet kroz čin pamćenja. Razlika između dva značenja istog predmeta zasnovana je na dvije različite faze akta svijesti (CHo 2007: 14). Od pojačane asocijativnosti nagomilavaju mu se prošli utisci u kratkom intervalu objektivnog vremena, pa dok mu slika djevojčice Mejmi još lebdi u umu, osjećaj protoka vremena kod Stredera se pojačava; iako nije ni sanjao da će Mejmi imati toliko da mu kaže, ona mu to saopštava kroz utiske koje reflektorsko pripovijedanje filtrira. To što ne čitamo gotovo nikakav dijalog samo potvrđuje snagu reflektorove uobrazilje - postao je siguran da je Mejmi prešla u njegov tabor, a i smatrao je da je Mejmi u dlaku shvatila šta se sa Čedom desilo, čime se ponovo dovodi na područje vrlo nesigurne metapercepcije i pretpostavki o tome kakvi su utisci drugih (dok, već smo 
vidjeli, njegovi sopstveni utisci često vode u pogrešnom pravcu). Na narednoj zabavi, koju priređuje gospođa De Vijone, a Čed pripomaže izborom svojih gostiju, Streder zbog spektakularnog ugođaja postaje još pogodniji za slobodnu izmjenu utisaka, do tolike mjere da svoju misiju poredi sa neminovnim prevrtanjem kočije čije uzde više ne drži gospođa Njusam, te da će ona svom težinom pasti na njega, a smatrajući da je Ced već spasen zahvaljujući izgradnji u novoj sredini, Mejmi tu nema šta da radi, pa Bilhemu nagovještava i brak sa mladom Amerikankom. Za Stredera, Mejmi je savršena, a ,jadni i grozni Čed prosto suviše dobar za nju" (DžEJMs 1955: 348). Ubrzo saznaje od Vejmarša da američka družina odlazi iz Pariza i očekuje posjetu od Sare Pokok (najavljenu kao „vrlo, vrlo dobru osobu”), ali mu Sara bez okolišnih diplomatskih konstrukcija saopštava ono što je on u posmatranju njenog posmatranja Čeda propustio da zapazi:

Imao je utisak da je sve ono što gospođa Pokok nije pokazala da je zapazila u Čedu kao deo njegovog preobražaja - sve ono što je takvo njeno držanje činilo namernim - da je sve to skupljeno u jednu veliku, razdrešenu balu i bačeno sa njenim rečima njemu u lice. (DžEJMs 1955: 369)

U žučnom razgovoru Sara insistira na polarizujućim razlikama između svoje majke i gospođe De Vijone uz upotrebu izraza „pristojna” i „nepristojna žena”, a Streder odgovara da je Čedov život divno preobražen njenim; i na kraju rasprave ostaju na suprotnim stranama, pošto je za Stredera Čedov razvoj „krasan”, a za njegovu sestru „grozan”. Naš lakovjerni junak poslije njenog odlaska osjeća olakšanje i misli da je sve zaista svršeno; dosad je na maštom iskrivljen način u mnogim procjenama omanuo, pa nam preostaje samo da sačekamo gdje će još spoznati neprimjenjivost svojih uvida.

Do spoznaje, ako ne umne, onda svakako čulne, dolazi vrlo brzo, kada se zapućuje u Čedov stan, koji budi uspomene na jedinstveni fenomen, glas iz soba koji je „čuo” pri prvom boravku u njemu tri mjeseca ranije, ali ne uspijeva da ga oživi, pa tako ostaje uskraćen za naknadno proživljeni utisak: „A danas je mogao samo da o tome danu pre tri meseca misli kao o kakvoj tački negde u dalekoj prošlosti” (DžEJMS 1955: 389). Upravo stoga što ne proživljava trenutak u kome se nala- 
zi, nego pušta da matica života teče mimo njega, Streder se ne može oduprijeti aktiviranom osjećaju frustracija i nepoklapanja sa fazom fenomenalnih zbivanja. Mladost koju je davno propustio sada osjeća kroz sliku mladog Bilhema i mlade Mejmi, ponajviše kroz tangentno sapostojanje u istom prostoru sa tim osobama novije generacije, ali taj utisak brzo blijedi, kada se samo odnosi na odsutnu, zatomljenu, neiskorišćenu mogućnost, a ne sam čin hedonizma. Čini mu se da taj gubitak može opipati:

U to se [...] pretvarala za njega ta mladost koju je tako davno propustio jedno čulno, konkretno prisustvo, vrlo tajanstveno ali i vrlo stvarno, nešto što je mogao da dodirne, da okuša, da omiriše, nešto što je potpuno mogao da čuje kako diše. (Ď̌Esms 1955: 390)

Pored vida, koji mu se stimuliše svakim prizorom i pokretom prefinjenog velegrada, Streder sublimira stimuluse svih čula u odocnjelo shvatanje i konkretizuje nesravnjivo veće moguće iskustvo u intenzivnu, ali kratkotrajnu senzaciju koja mu donekle nadoknađuje samoskrivljenu prazninu.

Do posljednjeg temeljnog saznanja Streder dolazi u neodređenom kraju francuske provincije nadomak Pariza, Džejmsu poznate iz direktnog iskustva, čitanja Mopasana i sličnih autora, a i sopstvene kreativnosti, uz namjerno isticanje maštovitog elementa koji odnosi prevagu nad realnim osobinama, pa stoga mjesto nije ni imenovano. Prostor kroz koji se kreće konceptualno sagledava kroz filter umjetnosti, sjećajući se (najvjerovatnije izmišljene) slike Emila Lambinea (Émile Lambinet), pejzažiste ruralnih scena iz XIX vijeka, koju je vidio davno ranije u jednoj bostonskoj radnji, ali nije imao novca da kupi. Prvobitni utisak je protokom vremena poprimio zaseban životni oblik i više se nije mogao razložiti na sastavne dijelove - ovakav umni konstrukt procesom redukcije zadobio je drukčiju formu i vrijednost u opažačevom estetski nastrojenom umu, i razumljivo je što su naslage percipirane umjetnosti sada nadvladavale objektivnu stvarnost. Osnovne crte koje pamti sa slike su: „Kestenjavo svetilište, vizija jedne osobite zelene boje, bagatelna cena, jablanovi, vrbe, trske, reka, sunčano, srebrnasto nebo, vidik senovit i šumovit” (DžEJMS 1955: 402). Iako 
je pošao na neko neodređeno mjesto, iz voza je izašao vrlo sigurno, kao da ide na sastanak. Taj stimulus je došao iz znaka koji ga je podsjetio na davno viđenu sliku - poklopili su se vrijeme, vazduh, svjetlost, boje i njegovo sopstveno raspoloženje, a i opis dočarava fluidnost između umjetnosti i realnosti, kada reflektor opaža da je duguljasti ram rasporedio svoje okvirne linije, jablanove i vrbe, trske i rijeku (kojoj ne želi ni da zna ime) u „vanredno srećnu kompoziciju”. Tako je Streder zakoračio u iluziju sjećanja na drugostepeni fenomen koji je sada prerastao polaznu osnovu opipljive geografije i obuzeo ga u epifanijskom stanju u kome vrijeme teče po sasvim nepredvidljivim pravilima, u skladu sa intenzitetom isijavanja prvobitnog ushićenja. Pustio je mašti na volju i uronio se u viziju šta će tih nekoliko opuštenih sati moći da čini oslobođen obaveza, i dok je uživao u ostvarenom svijetu nekadašnje slike, zamisao i stvarno okruženje doveo je u dugotrajnu harmoniju, primijetivši po završetku „snoviđenja” da je u okviru slike proveo čitav dan lutanja. U ovom ramu, Streder dolazi do ekstatičkog viđenja sopstvene drame, kada svu katastrofu sagledava kao da je ona sasvim drugačije biće od svog autora, a okolinu kao da je dekor ili pozornica njegove drame; egzistenti i pejzaž tog komada sada mu, konačno osviješćenom, izgledaju sasvim drukčije od vuletskih uslova i predstavljaju „savršenstvo svoje vrste”, pa se u okviru prostora sa koga posmatra - male bašte restorana nad rijekom - slika i drama bešavno stapaju. Izletni dan završava skoro omamljen brojnim skladnim utiscima koji se upotpunjuju i vremenski i prostorno i doživljajno, dok ne ugleda jedan detalj od koga se prene. Približava mu se neki čamac, koji posmatračev utisak dovršava upravo svojom inherentnom dinamikom u kompoziciji „slike” ili „scene”. Ponovo pokazuje usporenije shvatanje stvarnih pojava i maštovito učitavanje zahvaljujući podložnosti utiscima:

Odmah ih je ocenio kao dva vrlo srećna stvorenja - toga mladića podvrnutih rukava i tu mladu plavu i spokojnu ženu, koji su u dobrom raspoloženju došli sa nekog drugog mesta, jer su poznavali okolinu i znali šta mogu naći u ovom utočištu. (DžEJMS 1955: 409)

Za mladića se nekoliko trenutaka kasnije ispostavlja da je Čed, a žena nije tako mlada, pošto je u pitanju gospođa De Vijone - u ovom krun- 
skom trenutku Streder shvata, kada više nikakva mašta ne drži zavaravajući veo i ne omogućava obrazovanje iskrivljenog utiska, da veza između Čeda Njusama i Marije de Vijone baš i nije toliko platonska, i da vuletska pretpostavka da je nevinog američkog mladića iskvarila previjana francuska zavodnica više nema nikakvog osnova. U toku vesele večere Streder nije još bio pripremljen za donošenje utemeljenih zaključaka, ali je u miru pariske sobe to učinio kasnije, kada je život viđenih fenomena postao malo razbistrenije sjećanje, i naš izaslanik utvrdio da se radi o očitoj prisnosti, koju su Čed i gospođa u trenu zakrilili improvizovanim lažima i pretvaranjem. U kasnijem razgovoru sa gospođom De Vijone, koji je organizovala samo da bi vidjela koliko iskrivljeno predstavljenih stvari Streder može progutati, javlja mu se najoštrije zapažanje da je Čed, pored sveg gospođinog truda da ga načini najboljim, opet ostao samo Čed:

Njegova visoka ocena je nekako osveštala njeno delo. To delo, ma koliko bilo za divljenje, bilo je ipak ljudsko; ukratko, bilo je čudesno da saučesnik zemaljskih radosti, prijatnosti, zanosa [...] dostupnih svačijem iskustvu, bude tako nadzemaljski uzdizan. (DžEJMs 1955: 428)

Kada konačno uvidi da je fenomenu Čeda Njusama i njegove veze sa Francuskinjom pridavao okamenjeno značenje jedne faze opalescencije a zanemario sve ostale, shvata da se pored svih užitaka u Gradu svjetlosti, od krute vuletske moralnosti u percepciji dugo nije suštinski odvajao, nego je to učinio na nezgrapan način - krahom čitavog izaslanstva u Pariz, uz osjećaj oslobođenja od jednog načina života i uske moralne vizije koja ga je diskurzivno formirala cijeli prethodni život.

\section{Citirana Literatura}

BeyER, Christian. Edmund Husserl. The Stanford Encyclopedia of Philosophy (Summer 2018 Edition). Edward. N Zalta (ed.). https://plato.stanford. edu/archives/sum2018/entries/husserl/.

CHo, Kah Kyung. "History and Substance of Husserl's Logical Investigations". Kwok-Ying Lau and John J. Drummond (eds.). Husserl's Logical 
Investigations in the New Century: Western and Chinese Perspectives. Dordrecht: Springer, 2007, 1-20.

DžEJMS, Henri. Ambasadori, prev. Slobodan Jovanović. Beograd: Nolit, 1955.

DžEJMS, Henri. Umetnostromana. Prev. Marta Frajnd. Biljana Dojčinović (ur.).

Budućnost romana. Beograd: Službeni glasnik, 2012, 49-76.

Ellmann, Maud. The Nets of Modernism: Henry James, Virginia Woolf, James

Joyce, and Sigmund Freud. Cambridge: Cambridge University Press, 2010.

HusserL, Edmund. Logička istraživanja, sv. II, prev. Željko Pavić. Zagreb:

Breza, 2005.

Jochum, Klaus Peter. "Henry James's Ambassadors to Paris". Modern Language Studies, Vol. 13, No. 4, Henry James Issue, 1983, 109-120.

Kant, Imanuel. Kritika moći sudenja, prev. Nikola Popović, red. i pogovor Milan Damnjanović. Beograd: BIGZ, 1991.

Sergej Macura

\section{INTERPRETING IMPRESSIONS IN THE AMBASSADORS: STRETHER'S BELATED PHENOMENOLOGY}

\section{Summary}

The paper analyses the strand of belated and erroneous interpretations generated by the main character of James's novel The Ambassadors, Lambert Strether; from the very outset he is unaware of the opalescence of impressions in the liberal hedonistic environment of the Parisian upper class, so he reads them through an unsuitable framework burdened with the narrow-minded morality of smalltown Massachusetts. Maladroit at interpreting ambivalent phenomena and relations, he makes one mistake after another while thinking that he penetrates to the essence of things - by misjudging Chad Newsome's character, as well as his relationships with Marie and Jeanne de Vionnet, just to experience artistic pleasure and phenomenological sobering at the end, in a revived memory of a landscape painting.

Keywords: Ambassadors, Henry James, Strether, consciousness, impressions, sensations, intentions, objects.

Univerzitet u Beogradu

Filološki fakultet

sergej.macura@fil.bg.ac.rs 